\title{
Assessment of the effectiveness of flood adaptation strategies for HCMC
}

\author{
R. Lasage ${ }^{1}$, T. I. E. Veldkamp ${ }^{1}$, H. de Moel $^{1}$, T. C. $\operatorname{Van}^{2}$, H. L. Phi ${ }^{3}$, P. Vellinga ${ }^{1}$, and J. C. J. H. Aerts ${ }^{1}$ \\ ${ }^{1}$ Institute for Environmental Studies (IVM), VU University Amsterdam, the Netherlands \\ ${ }^{2}$ The Water Resources University (WRU), Ho Chi Minh City, Vietnam \\ ${ }^{3}$ Center of Water Management and Climate Change, Ho Chi Minh City, Vietnam \\ Correspondence to: R. Lasage (ralph.lasage@vu.nl)
}

Received: 18 December 2013 - Published in Nat. Hazards Earth Syst. Sci. Discuss.: 17 January 2014

Revised: - Accepted: 27 April 2014 - Published: 6 June 2014

\begin{abstract}
Coastal cities are vulnerable to flooding, and flood risk to coastal cities will increase due to sea-level rise. Moreover, Asian cities in particular are subject to considerable population growth and associated urban developments, increasing this risk even more. Empirical data on vulnerability and the cost and benefits of flood risk reduction measures are therefore paramount for sustainable development of these cities. This paper presents an approach to explore the impacts of sea-level rise and socio-economic developments on flood risk for the flood-prone District 4 in Ho Chi Minh City, Vietnam, and to develop and evaluate the effects of different adaptation strategies (new levees, dry- and wet proofing of buildings and elevating roads and buildings).

A flood damage model was developed to simulate current and future flood risk using the results from a household survey to establish stage-damage curves for residential buildings. The model has been used to assess the effects of several participatory developed adaptation strategies to reduce flood risk, expressed in expected annual damage (EAD). Adaptation strategies were evaluated assuming combinations of both sea-level scenarios and land-use scenarios. Together with information on costs of these strategies, we calculated the benefit-cost ratio and net present value for the adaptation strategies until 2100 , taking into account depreciation rates of $2.5 \%$ and $5 \%$.

The results of this modelling study indicate that the current flood risk in District 4 is USD 0.31 million per year, increasing up to USD 0.78 million per year in 2100 . The net present value and benefit-cost ratios using a discount rate of $5 \%$ range from USD -107 to -1.5 million, and from 0.086 to 0.796 for the different strategies. Using a discount rate
\end{abstract}

of $2.5 \%$ leads to an increase in both net present value and benefit-cost ratio. The adaptation strategies wet-proofing and dry-proofing generate the best results using these economic indicators. The information on different strategies will be used by the government of Ho Chi Minh City to determine a new flood protection strategy. Future research should focus on gathering empirical data right after a flood on the occurring damage, as this appears to be the most uncertain factor in the risk assessment.

\section{Introduction}

Coastal cities are vulnerable to flood risk, as shown by the recent floods in New York City, USA (2012), Manila, Philippines $(2012,2013)$ and Brisbane, Australia (2011). These floods vividly illustrate that coastal mega-cities have increasing vulnerability to storm-surge flooding (Nicholls et al., 2008; UN, 2012). By the middle of this century, the majority of the world's population will live in cities in or near deltas, estuaries or coastal zones, resulting in even more people located in highly exposed areas (Jongman et al., 2012). Such socio-economic trends further amplify the possible consequences of future floods, as more people move toward urban delta areas, and capital is continuously invested in ports, industrial centres and financial businesses in these flood-prone areas. Moreover, climate change and sea-level rise may further amplify the frequency, intensity and duration of flood events (IPCC, 2007). Ho Chi Minh City (HCMC) in Vietnam is a typical example of a vulnerable coastal city, which is frequently hit by floods. In fact, the low-lying parts of 
the city are flooded each spring tide. However, while recent research has focused on vulnerable coastal cities in Europe and the US, relatively little is known about the flood risk of coastal cities in Asia, including HCMC (Huq et al., 2007; ADB, 2010). In a global assessment by Hanson et al. (2011), HCMC is ranked in the top-20 most risky cities, when considering the size of the population exposed to coastal flooding (e.g. flooding by the sea).

A challenge in planning for flood adaptation is to the quantify trends in risks, and calculate the costs and benefits of different adaptation strategies to reduce those risks (Dawson et al., 2011; Ranger et al., 2011). This requires input from different disciplines, varying from coupled hydrodynamic flood modelling (e.g. Winsemius et al., 2013), catastrophe risk models of the city's exposed assets (Grossi et al., 2005) to economic evaluation of risk management strategies, including policy, insurance and engineering measures, in order to calculate the cost and expected benefits of different strategies over a given period of time (e.g. Hallegate, 2006). There are many studies that quantify flood hazard and expected changes in the hazard due to sea-level rise (Nicholls and Cazenave, 2010). Other studies use flood risk assessment models, focusing both on the flood hazard, and on flood exposure and vulnerability (Apel et al., 2008; Merz and Thieken, 2009; de Moel and Aerts, 2011; Ward et al., 2011a). Some of these studies use catastrophe risk models to calculate risk reduction for different flood adaptation measures on local to regional scales (e.g. Veerbeek and Zevenbergen, 2009; Bouwer et al., 2010; Koks et al., 2014; de Moel et al., 2014; Aerts et al., 2013), and for others on the river basin scale (e.g. te Linde et al., 2011; Poussin et al., 2012). Few studies, however, have assessed the efficiency of those flood adaptation measures in terms of costs and benefits (e.g. Dawson et al., 2011), and only some make use of specific depth-damage relations of the studied area.

Storch and Downes (2011) recently assessed the exposure of HCMC to flooding by coupling data on urban development with projected maps of sea-level rise scenarios. Their conclusion is that socio-economic development and urban expansion are the main drivers for the increased exposure to flooding compared to the influence of sea-level rise. This conclusion is supported by Adikari et al. (2010). The Asian Development Bank (ADB) assessed the effect of a flood control plan as an adaptation to reduce the vulnerability of HCMC to increased flooding as a result of climate change and sea level rise. However, they only assessed the reduced exposure of assets (ADB, 2010). Hence, existing studies have not assessed the risk (often expressed as expected annual damage, EAD) defined as a function of the flood hazard and its probability, and the consequences (the exposed assets and their vulnerability; Kron, 2002). Partly this is because stage-damage curves are not available for South East Asian cities. As the EAD for flooding has not yet been established, it was also not possible to assess the cost-effectiveness of different flood adaptation measures for HCMC.
Different types of flood adaptation strategies are available to reduce flood risk. These consist of strategies to reduce the probability of flooding, for example dikes and levees (Merz et al., 2010; Poussin, 2012), and strategies to reduce the consequences of flooding, for example wet- and dry-proofing of houses, and elevating an area or individual houses (Kreibich and Thieken, 2009; Aerts and Botzen, 2011), as well as measures of evacuation and early warning (Merz et al., 2010; de Moel et al., 2014).

The main goal of this study is to conduct a benefit-cost analyses of alternative flood adaptation options for HCMC, assuming different scenarios of changes in land use and climate. To achieve this assessment, we combined a participatory approach to identify adaptation options and vulnerability, with a model-based assessment of benefits and costs, in which stage-damage curves based on a survey in HCMC are used. In this assessment we only include direct impacts of floods on urban land uses. Indirect effects, and societal and environmental effects, are not included. This method is applied to District 4 in HCMC, one of the most exposed parts of the city. Section 2 describes the method and data, including the case study area. Sections 3, 4, and 5 present, respectively, the results, discussion and conclusions.

\section{Method and data}

Figure 1 is an overview of the methodology of this paper. We used a flood damage model to calculate flood risk and expected annual damage, with and without a proposed flood management strategy. The damage model used synthetic flood hazard scenarios as input, which were produced by a coupled hydrological-hydrodynamic model. Future scenarios include sea-level rise due to climate change, and projected urban growth. The effectiveness (risk reduction) of each strategy and its costs were then evaluated in a benefitcost analysis under the various future scenarios. We applied a participatory approach to develop several key parts of the method, such as novel stage-damage curves and adaptation strategies, both tailored to HCMC.

\subsection{Case study: Ho Chi Minh City focusing on District 4}

Ho Chi Minh City is located in the south of Vietnam in the floodplain of the Dong-Nai and the Sai-Gon river systems (Fig. 2), an area enclosed by the Mekong River system in the western part and the East Sea on the eastern side (Vo, 2009). Some $40-45 \%$ of the city's land cover has an elevation between 0 and $1 \mathrm{~m}$ a.s.l., while $15-20 \%$ of the land is located at $1-2 \mathrm{~m}$ and only the northern area is located at higher levels (> 4 m a.s.l.) (World Bank, 2010). The city consists of 24 administrative districts (subdivided into 322 wards and communes and five townships), which vary in size, population density and land use (World Bank, 2010; ADB, 2010). 


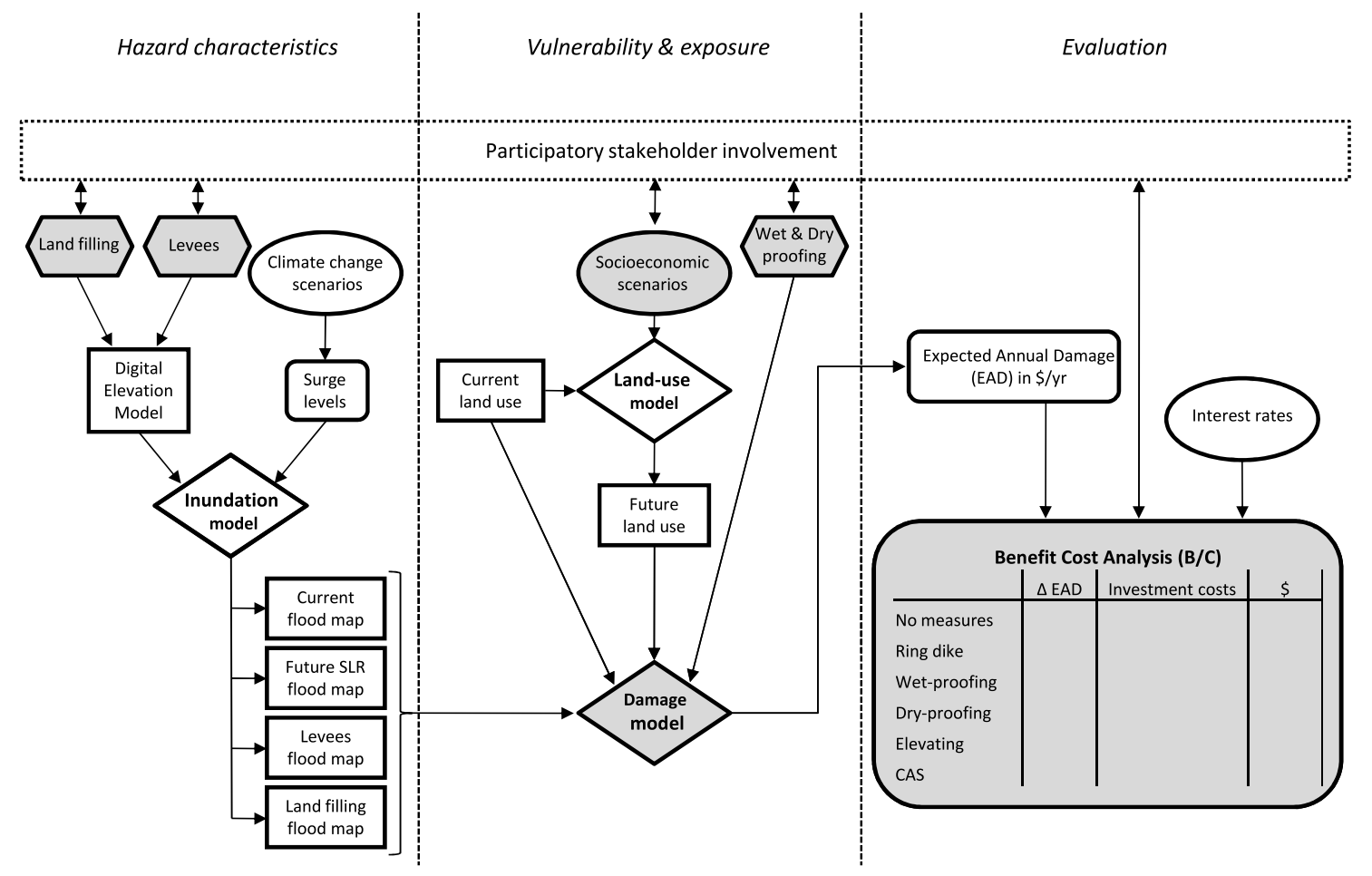

Figure 1. Overview of methods applied in this paper (filled shapes indicate use of participatory developed information, ovals are external scenarios, diamonds are models, squared boxes are maps, polygons are adaptation strategies, and rounded squared boxes are evaluation criteria).

Ho Chi Minh City is a fast-growing city. The mean annual GDP growth was $7.3 \%$ per year over the period 20012010 (CVCP, 2011) and the number of inhabitants rose from 3.8 million to 7.1 million between 1986 and 2010, excluding an additional 2 million unregistered migrants (Storch and Downes, 2011). By 2025, the city is expected to grow further to at least 10 million people (MPI, 2011), and economic growth is projected at 7-8\% per year (CVCP, 2011; IMF, 2013). The HCMC region is an economic hub for the whole of Vietnam and generates one-third of the national GDP (Eckert et al., 2009).

The city is exposed to flooding from the sea and rivers, and this hazard is expected to increase in the future as a result of sea-level rise (SLR) and soil subsidence (ADB, 2010; World Bank, 2010; Storch and Downes, 2011). Storch and Downes (2011) show that, currently, $160 \mathrm{~km}^{2}$, or $32 \%$ of the built-up area is exposed to flooding. This will increase up to $360 \mathrm{~km}^{2}$, or $48 \%$ when only taking into account urban development until 2025. They also identify District 4 as one of the most exposed areas in HCMC, and this is the subject of our analysis (see Fig. 1). We focus on District 4 because the spatial flood adaptation plans and data are available for this part of the city, enabling a detailed analysis of risk, including exposed population and assets. The district covers an area of $3 \mathrm{~km}^{2}$ and is a typical example of the densely populated urban centre of HCMC. The main land use is residential buildings, intermingled with small shops (often as part of the residential houses), large shops and offices (see Fig. 3).

\subsection{Hydrological and hydrodynamic simulations}

Inundation depths used in this research are modelled with the Mike 11 hydraulic software package. Mike 11 is a modelling program for the 1-D simulation of water quantity, quality and sediment transport in different types of water bodies (DHI, 2003). Impacts and effects of floods can be visualized using Mike 11 in combination with a GIS interface (DHI, 2002; CDWR, 2006). The resulting flood inundation maps can be used as input for flood damage assessment studies.

The inundation maps have a spatial resolution of $20 \times$ $20 \mathrm{~m}^{2}$, and are composed for five different return periods $(1 / 10,1 / 25,1 / 50,1 / 100,1 / 1000)$ under the current sea level and river discharge, and for five return periods including a sea-level rise scenario of $+30 \mathrm{~cm}(\mathrm{SLR}+30)$ in the year 2050 (FIM, 2013a) and current river discharge.

\subsection{Calculating the Expected Annual Damage}

In order to calculate the EAD, we used a typical approach using damage curves (similar to Klijn et al., 2007; de Moel and Aerts, 2011). This requires two inputs: a land-use map for determining exposed assets, and an inundation map. These inputs are combined using the stage-damage curves, which 


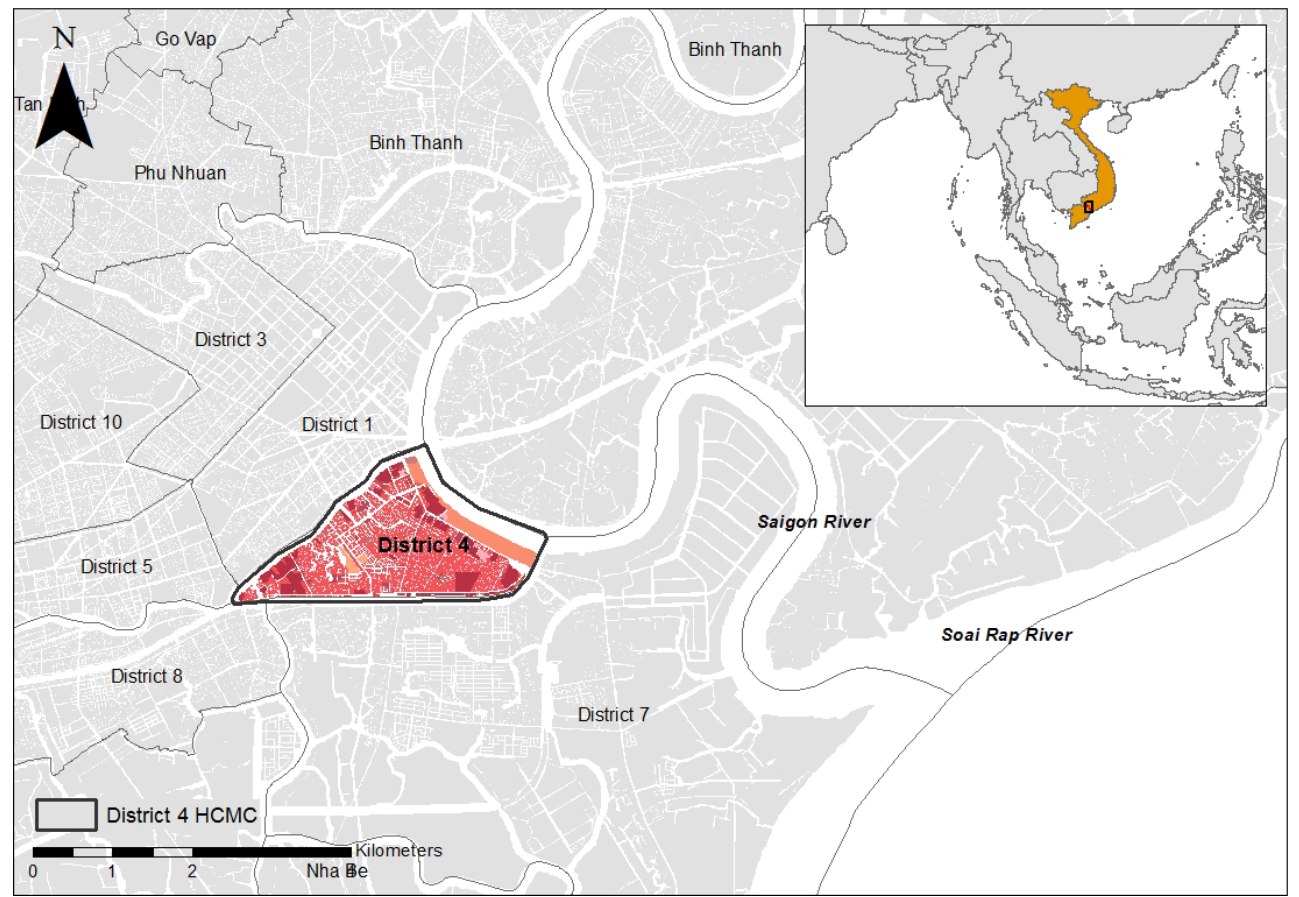

Figure 2. Map of the study area in Ho Chi Minh City.

per class of exposed assets yields the damage to the asset as a function of inundation depth. The EAD is calculated by aggregating damage estimates of different probabilities by taking the integral under the exceedance probability-damage curve (risk curve) (Grossi et al., 2005; Meyer et al., 2009). Ward et al. (2011b) have shown that flood damage related to five return periods (as available in this study: see Sect. 2.2) with a sufficient spread (low and high probabilities) are sufficient to estimate the EAD.

The exposed assets are classified in six classes (see Table 1), and are derived from an existing land-use map for HCMC, representing the situation in 2005 (ADB, 2010). This map has a resolution of $20 \times 20 \mathrm{~m}^{2}$, and was updated and refined on the basis of the presence of two types of residential buildings in sectors in District 4 . To assess the change in EAD due to socio-economic developments, we have used the land-use map 2025, developed by the government of HCMC as part of the socio-economic Master Plan 2025 (DPA, 2010). We assume land use for 2050 to be the same as land use in 2025, since projections of land use in 2050 are not available. When using the future land-use scenario in the analysis, we have interpolated land-use change between 2013 ("current situation") and the year 2025. After 2025, land use remains the same until 2050.

Hence, as input for calculating the change in EAD, we use two land-use scenarios and two sea-level scenarios (Sect. 2.2). One represents the baseline situation, and the other represents the situation in 2050. Using different combinations of land-use and sea-level scenarios makes it possible to compare the relative importance of land-use change and sea-level rise on the EAD.

\section{Household survey: deriving stage-damage functions}

To calculate damage, we combine information on land use and inundation depth using stage-damage functions. A damage curve provides the expected damage for a given inundation depth (as a proportion of the maximum damage), for each land-use type. Stage-damage functions for HCMC were not available prior to this research. In order to establish the relation between flood depth and damage for HCMC, a household survey was carried out. The survey was carried out in 17 districts of HCMC which were exposed to flooding in 2011. The majority of these districts are located in the older part of the city. A few are located at newly developed residential areas. In analysis of the survey data, this has been taken into account by differentiating between low-rise houses, and higher-rise houses. The experienced flooding depth varies between the districts and the interview locations. In total 659 households were interviewed during a face-to-face interview using a structured questionnaire. The questionnaire covered the following topics: general information of households; past flood inundation; inundation damage; measures for inundation control; willingness to pay for flood protection; maximum damage to house; maximum damage to furniture and assets; suggestions as to which actions the HCMC government, flood control programme, and communities respectively should undertake to reduce flood risk; and the potential damage caused by higher inundation levels. The households 


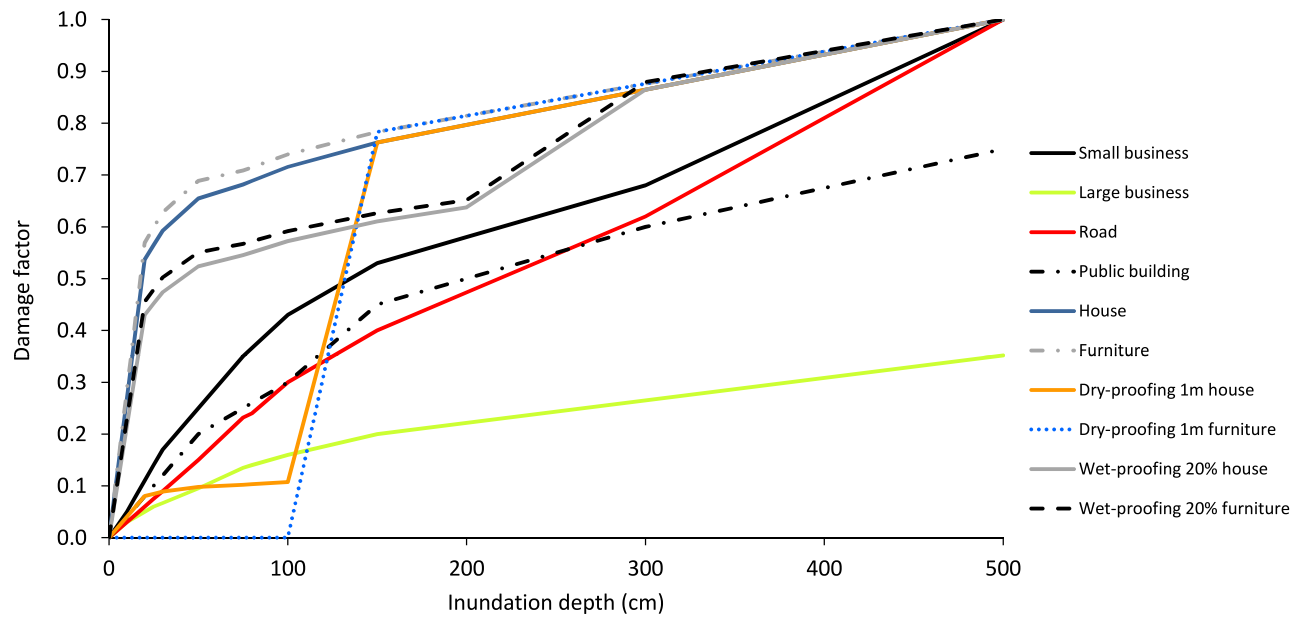

Figure 3. Stage-damage curves as used in this study, including the stage-damage curves for dry- and wet-proofing.

Table 1. Maximum damage and damage factors $(\%)$ per $\mathrm{cm}$ inundation depth.

\begin{tabular}{|c|c|c|c|c|c|c|c|c|c|c|c|c|c|c|}
\hline \multirow[t]{2}{*}{ LU class } & \multirow{2}{*}{$\begin{array}{l}\text { Max. damage } \\
\left(\text { USD per } \mathrm{m}^{2} \text { ) }\right.\end{array}$} & \multicolumn{13}{|c|}{ Damage factor $(\%)$ per $\mathrm{cm}$ inundation depth } \\
\hline & & 10 & 15 & 20 & 25 & 30 & 50 & 75 & 80 & 100 & 150 & 200 & 300 & 500 \\
\hline Residential $<2$ floors & 7.46 & 0.268 & 0.403 & 0.537 & 0.565 & 0.593 & 0.655 & 0.683 & 0.689 & 0.716 & 0.764 & 0.797 & 0.865 & 1.000 \\
\hline Residential $\geq 2$ floors & 28.30 & 0.268 & 0.403 & 0.537 & 0.565 & 0.593 & 0.655 & 0.683 & 0.689 & 0.716 & 0.764 & 0.797 & 0.865 & 1.000 \\
\hline Furniture $<2$ floors & 2.78 & 0.285 & 0.427 & 0.569 & 0.599 & 0.628 & 0.689 & 0.709 & 0.715 & 0.740 & 0.783 & 0.814 & 0.876 & 1.000 \\
\hline Furniture $\geq 2$ floors & 5.91 & 0.285 & 0.427 & 0.569 & 0.599 & 0.628 & 0.689 & 0.709 & 0.715 & 0.740 & 0.783 & 0.814 & 0.876 & 1.000 \\
\hline Small business & 36.20 & 0.050 & 0.080 & 0.110 & 0.140 & 0.170 & 0.250 & 0.350 & 0.366 & 0.430 & 0.530 & 0.580 & 0.680 & 1.000 \\
\hline Large business & 36.20 & 0.030 & 0.040 & 0.050 & 0.060 & 0.067 & 0.095 & 0.135 & 0.140 & 0.160 & 0.200 & 0.222 & 0.265 & 0.352 \\
\hline Road & 0.40 & 0.030 & 0.045 & 0.060 & 0.075 & 0.090 & 0.150 & 0.232 & 0.240 & 0.300 & 0.400 & 0.473 & 0.620 & 1.000 \\
\hline Public building & 26.10 & 0.040 & 0.060 & 0.080 & 0.100 & 0.120 & 0.200 & 0.250 & 0.260 & 0.300 & 0.450 & 0.500 & 0.600 & 0.750 \\
\hline
\end{tabular}

were located in districts exposed to the flooding of 2011 , which was used as a reference flood. This recent flood enabled the interviewed households to better recollect the impacts and damage. A household selection was made, using an inundation map of the flood of 2011, and with additional information on the specifications of each ward from the local people's committee. The questionnaire was pre-tested on 100 households before the survey was executed.

Of the respondents, $54 \%$ were female, and the per capita income for $24 \%$ of the respondents was below VND 1 million per month (USD 48), corresponding with the threshold for poor families according to the HCMC government; $86 \%$ of the respondents were the owners of their house, and the average value of the houses was VND 2.5 billion (USD 117000 ); $52 \%$ of the houses were older than 15 years and $11 \%$ were less than 5 years old. Out of the 659 household interviews, 644 had information on flood depth, damage to the house, damage to the furniture, value of the property, size of the ground floor, number of floors, and expected damage if the flood depth were to increase by 20,40 , and $100 \mathrm{~cm}$.

On the basis of the damage data for four flood depths, we developed stage-damage curves. The maximum flood depth reported by the respondents was $120 \mathrm{~cm}$. For damage occurring at higher flood levels up to $5 \mathrm{~m}$, we have extrapolated the data, assuming a slope that is half of the slope between the reported damages of $60 \mathrm{~cm}$ and $120 \mathrm{~cm}$, in line with the flattening off found in many residential damage curves (see e.g. de Moel et al., 2014). We distinguished two types of houses: up to two floors (e.g. ground floor and first floor), and houses with more than two floors, representing, respectively, cheaper and more expensive houses. The stagedamage curves are similar (Fig. 3), but, the maximum damage costs are USD 7.46 and USD 22.40 per $\mathrm{m}^{2}$, respectively (Table 1). The stage-damage curve for furniture was developed in a similar way. There is no difference in the shape of the curve, but the maximum damage is again different; USD 2.78 for houses of up to two floors, and USD 5.91 for houses of more than two floors, respectively.

For other land-use classes, we have estimated the maximum damage values, using the ratio of maximum damage to the residential land use to that of other land uses, as used by FIM (2013a). The maximum damage values, expressed in 2012 USD per $\mathrm{m}^{2}$, and the damage factor proportions for all the land-use classes and inundation depths are shown in Table 1. Examples of the spatial distribution of damage caused 
by floods with different return periods for two land-use scenarios are shown in Fig. 6.

\subsection{Participatory development of flood management strategies}

Seven design workshops (referred to as "Charettes") were organized in the context of the VCAPS project (VCAPS, 2013) to develop flood-adaptation strategies. The local culture was taken into account in the organization of the workshops, in order to develop a culture-sensitive participatory process (Hostovsky and Mclaren, 2005). For instance at the first sessions of the workshop cycle, we only asked feedback from the participants on the activities and policies of the organization they were employed at, as it is not customary to give one's opinion on the activities and policies of other organizations. At a later stage, after trust was built, the participants were willing to take a wider perspective and suggest what potentially could be changed, also on topics that were not directly the responsibilities of their organization. Also, the phasing of the participants activities was tailored to the Vietnamese circumstances, starting with bringing together factual information, like maps, and policies and plans, which does not include giving opinions. Most participants were hesitant to give their opinion at the beginning, as it might be different to what their boss thought (Huntjens et al., 2014). We referred to workshops as Charettes, because this concept was not known yet in Vietnam. Hence, there were no expectations on which activities will be included in the meeting, what was expected from the participants and how they should behave. As a result, the Charettes were an open style of meeting, where the participants were invited and stimulated to actively participate. We also used the first workshops to train people in the understanding and use of scenarios. This was new for the participants, and different from normal plan making, which includes the idea that a plan will be implemented once it has been approved. The concept that the future might develop in different directions, which are equally likely to happen, was a big challenge. After several workshops, the participants had become involved in the process and more comfortable in making suggestions to adjust plans, even if these had already been approved. From that moment onward, the focus of the workshops shifted to developing and designing new measures and strategies. The first set of workshops focused on the current situation and the vulnerabilities in HCMC. Other workshops then focused on climate and socioeconomic change, how to assess impacts of climate change, the different types of adaptive measures available, and other issues and characteristics of importance for the evaluation of an adaptation strategy by the Vietnamese government. The participants of the workshops were the staff of governmental departments, selected on the basis of their expertise in relevant topics. For each workshop additional experts (universities, NGOs, etc.) were invited. It should be noted that the role of NGOs in Vietnam is smaller than in many other countries.
Citizens express their concerns mostly through organizations that are authorized and financed by the State. In this way, the government mobilizes public support, whilst maintaining control (Huntjens et al., 2014). The right of the population to participate in local government affairs through the People's Committee is formalized in the Grassroots Democracy Decree of 1998 (Duong, 2004), which was updated in 2003 and 2007. An interactive approach was applied using a Touch Table (Arciniegas et al., 2011), drawing on large maps, and other tools, with emphasis on creation by the stakeholders, and facilitation by Dutch experts, ensuring that the outcomes of the workshops represented the visions of the participants, which should assure acceptability. Five flood management strategies were developed: (S1) a strategy protecting the district with levees, hence aiming at reducing flood probability; strategies aiming to reduce flood exposure and sensitivity by (S2) wet-, and (S3) dry-proofing buildings; (S4) elevating roads and buildings, aiming to reduce flood exposure; and (S5) a combination of several measures (referred to as "CAS") to reduce flood risk with adjusted land use, which additionally would increase the spatial quality of District 4 . These strategies were drafted by the experts using inputs of the stakeholders during the workshops and the results of the household survey. The draft strategies were presented to the stakeholders in a subsequent workshop, and where necessary they were adjusted accordingly.

\subsection{1 (S1) Ring dike strategy}

This strategy consists of a series of levees with a height of two metres above average water level, or $3.37 \mathrm{~m}$ a.s.l. forming a ring around District 4 . This dike height is used by the Vietnamese government (FIM, 2013a). This ring dike protects District 4 on all sides from floods by the Rach Bên Nghé River in the north, the Te Channel in the south (Kên Té) and the Saigon River on the east side. The waterways of the district, which are in contact with the main water bodies, can be closed by sluices and floodgates. We assume there will be no damage when flood levels are below $3.37 \mathrm{~m}$ a.s.l. If water levels are higher, the levee will be overtopped and we assume the water level in the district will reach the same level as in the main water bodies.

\subsection{2 (S2) Wet-proofing}

Wet-proofing reduces the damage to the house and furniture, but water can still enter the house. Measures include, for example, putting expensive appliances at a higher elevation in the house, and having the power sockets higher above the ground. Existing studies (some using empirical data) show a reduction in the damage of $35 \%$ to $40 \%$ when wet floodproofing is applied (DEFRA, 2008; Poussin et al., 2012; De Moel et al., 2014). However, this district is regularly flooded, and, hence the inhabitants have already taken several measures to reduce the impact on their houses and belongings. 


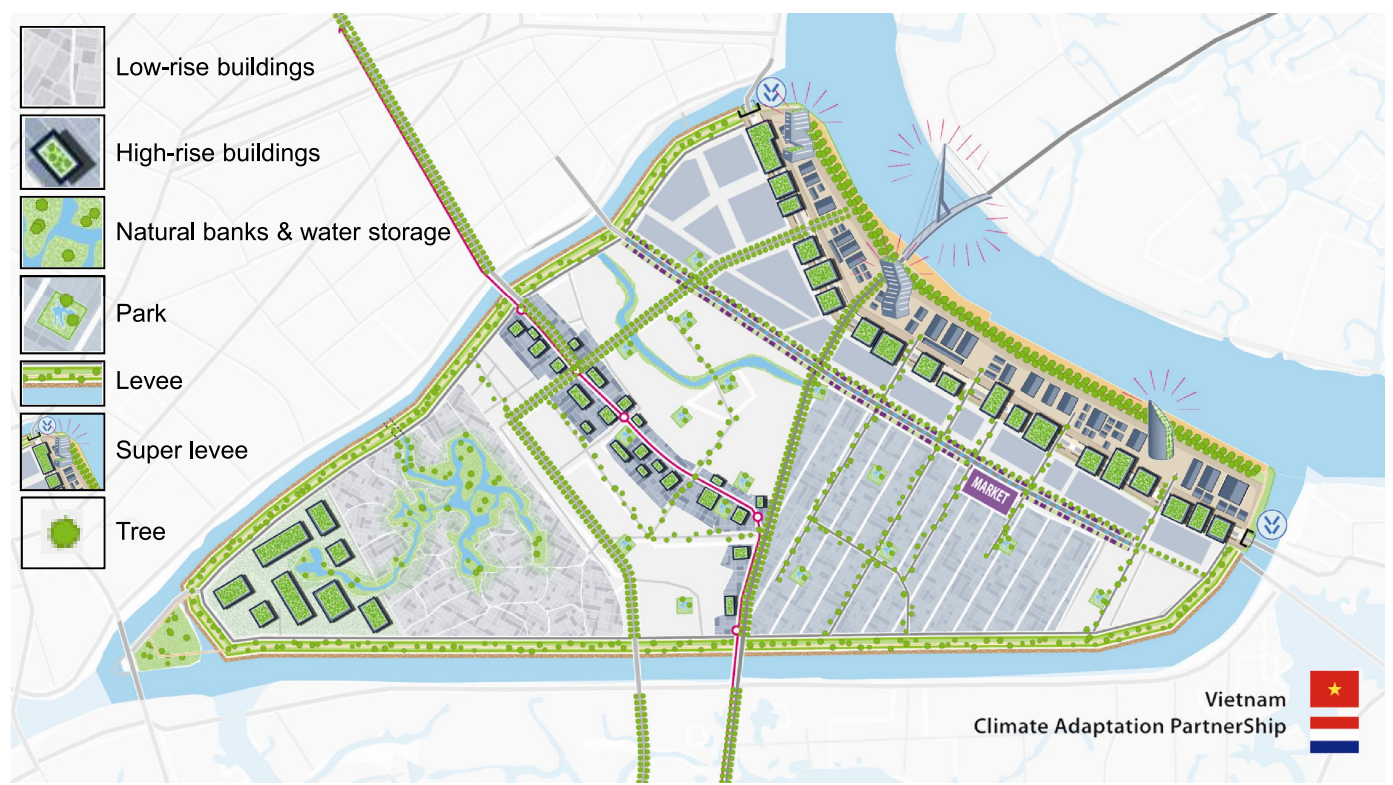

Figure 4. Spatial plan resulting from the participatory developed climate adaptation strategy for Ho Chi Minh City (Adopted from: VCAPS, 2013).

On the basis of discussions with local experts during the workshops and field visits, we assume that damage will be reduced by $20 \%$ compared with households that do not take wet-proofing measures. As wet-proofing involves moving assets to higher floors or raising them to a certain elevation, we assume that the measure is no longer effective when the inundation depth is more than $3 \mathrm{~m}$. At this point, the second floor will also be flooded. Hence, for wet-proofed land use the damage factor curve is reduced by $20 \%$ up to two metres, and rises to the normal damage curve in the following metre. Figure 3 shows the adjusted stage-damage curve for wet-proofing, compared with the original curves.

\subsection{3 (S3) Dry-proofing}

Dry-proofing aims to seal the house to prevent water from entering (FEMA, 2009). It accounts for both water entering via the doors, windows and walls, and for water entering via the sewage system. It is roughly effective up to a water depth of $1 \mathrm{~m}$, when the pressure of the water becomes too large for the walls of a building (Bubeck and de Moel, 2010; De Moel et al., 2014). If the flood depth is more than $1 \mathrm{~m}$, the damage will quickly rise to be equal to the non-dry-proofed damage curve (Fig. 3). In the damage model we have included dry-proofing by reducing damage to the house by $85 \%$, and damage to the furniture by $100 \%$ compared with the standard stage-damage curves. Between $1 \mathrm{~m}$ and $1.5 \mathrm{~m}$, the curve rises toward the standard curve. Above that level, the curve is similar to the standard curve.

\subsection{4 (S4) Elevating roads and buildings}

District 4 will undergo major restructuring in the coming decades, and most buildings will be replaced by new ones (VCAPS, 2013). This process provides the opportunity to raise the ground level on which the buildings are built. Recently built commercial and residential buildings are already at higher elevations as compared with the surrounding (older) buildings. In order to assess the damage-reducing effect of elevating new buildings, we included three elevation levels where the whole district is elevated. The three elevation levels are:

- Elevation of 2.11 ma.s.l $(S 4+2.11)$ This is based on the existing building code, which states that residential buildings in flood prone areas should be at least higher than the maximum water $\left(H_{\max }\right)$ level with a return period of 10 years (Ministry of Construction, 2008). In this study, we take the $H_{\max }$ for a $1 / 10$ flood, assuming the $\mathrm{SLR}+30$ scenario.

- Elevation of 2.53 ma.s.l. $(S 4+2.53)$ This is based on the higher protection level for residential areas in the existing building code, which takes the flood level with a return period of 100 years, assuming the SLR +30 scenario, and an additional $30 \mathrm{~cm}$ specifically for public buildings.

- Elevation of 3.37 ma.s.l. $(S 4+3.37)$ This is based on the height of the levees in S1. This strategy is included to enable a comparison of strategy S4 with the strategies $\mathrm{S} 1$ and S5, which both protect the district for a flood up to $3.37 \mathrm{~m}$ a.s.l. 
In the model we have applied this measure by subtracting the elevations from the flood levels, and calculating the damage, which occurs in areas that are then still flooded, using the water levels with return periods as described in Sect. 2.2.

\subsection{5 (S5) CAS}

The climate adaptation strategy (CAS) consists of multiple measures to cope with the impacts of climate change, and to improve the living conditions in District 4. Measures include the construction of levees around the district, where the levee at the Saigon river is a designed as a wide "super levee". This wide levee includes a tunnel for a highway, and high-rise buildings on top, and has room for multiple functions along the water shore. The plan aims at improving future living conditions, taking into account the urban heat island effect, flood risk, and an improved public subway system, while maintaining the character of different parts of the district. This led to a design with more intense land use and high-rise buildings on the super levee and close to the public transport stations. Lower densities and smaller buildings are located close to the creeks, and in parts of the district further away from the subway stations (Fig. 5). In these areas, space is created for storing excess rainwater. In the analysis we focus on measures to reduce flood risk.

\subsection{Cost estimates for flood management strategies}

We calculated direct tangible costs for all five flood management strategies, and assume indirect costs to be equal to direct tangible costs (Toyoda, 2008). Other costs are excluded from the analysis as data were not available. These are: intangible costs; damage to vehicles; damage to infrastructure; costs related to recovery after a flood (for example cleaning costs); and the effects on living conditions. No inflation figures are used, so maintenance costs remain the same over the whole period of analysis. We apply an exchange rate of USD 48 to VND 1 million. The investment costs as reported in the literature for the elements of the five different strategies are summarized in Table 2. To enable a consistent comparison of the different strategies, we have assumed they will all have a lifetime of at least 87 years, until 2100. For the strategies including dikes this lifetime is easily achievable (Aerts et al., 2013; FIM, 2013b). The elevating strategy consists of adding additional sand to the area, which will stay there forever. For the wet- and dry-proofing measures, shorter lifetimes are reported in the literature. For instance, Kreibrich et al. (2009) report a lifetime of 75 years for dry-proofing of cellars. Hence, the assumption of a lifetime of 87 years might lead to a slight underestimation of the investment costs for dry- and wet-proofing.

S1. For the ring dike, we used data on construction and maintenance costs per kilometre for levees, which were studied in detail by FIM (2013a). We assume it will take 5 years to finish the construction of the levees around the district, that the investments are equal over those 5 years, and that the EAD will be reduced after completion of the whole levee.

S2. For wet-proofing, we assume that all buildings in District 4 are wet-proofed, as the whole district is exposed to flooding. District 4 has circa 29000 residential houses. The costs are USD 258 per house, and consist of taking measures to put household belongings on a higher level in the house, and move the power sockets to above flood level. The costs for moving furniture and cleaning after the flood are excluded from the analysis. The data originate from our survey, with added input from local experts. As wet-proofing is relatively simple, we assume the measures are in place after 1 year.

S3. For dry-proofing, we use the cost ratio between wetand dry-proofing provided by Botzen et al. (2013). In their study, dry-proofing is 2.5 times more expensive per house than wet-proofing. In this strategy, all buildings in the district are dry-proofed. As dry-proofing is more complex than wet-proofing, we assume it will take 3 years for all buildings in the district to be dryproofed and that every year one-third of the buildings will be dry-proofed. Hence, the EAD will be reduced by even steps over these 3 years. The investment costs of USD 645 per house are low compared to the figures of Kreibrich et al. (2009) and Botzen et al. (2014). Those studies were performed in Germany and New York, respectively, where building materials and labour costs are much higher than in HCMC. Our study uses the lower range of investment costs for the measures.

S4. For elevation (elevating the whole district), we used the total amount of sand necessary to increase the height of the whole district to the different elevations. The total $\mathrm{m}^{3}$ of sand is multiplied by the price of sand of USD 14.60 per $\mathrm{m}^{3}$, which includes transport (FIM, 2013b), and we apply a factor of 1.5 to account for subsidence of the soil. For comparison, the cubic-metre price of sand in the Netherlands is also shown in Table 2, which is USD 67.63 per $\mathrm{m}^{3}$ including transport (van Hussen, 2013). We assume that the elevation takes place up to 2025 , and then the whole district will be elevated to the different heights of this strategy. The investment costs are equal for the 12 years it takes to implement, and the damage is reduced by $1 / 12$ th per year, until 2025.

S5. For the $C A S$, we have to differentiate between normal levees and the super levee next to the Saigon river. Cost data for the levee is calculated in the same way as for strategy 1 . For the construction and maintenance costs of the super levee we have used the ratio between investment costs for a normal levee and those for a super levee, calculated on the basis of Aerts et al. (2013). A 
(A) Inundation depth - No SLR: $1 / 10$

(B) Inundation depth - No SLR: 1/100

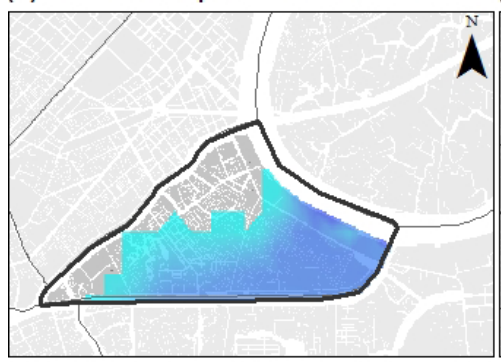

(C) Inundation depth - No SLR: 1/1000

(D) Inundation depth - SLR: $1 / 10$
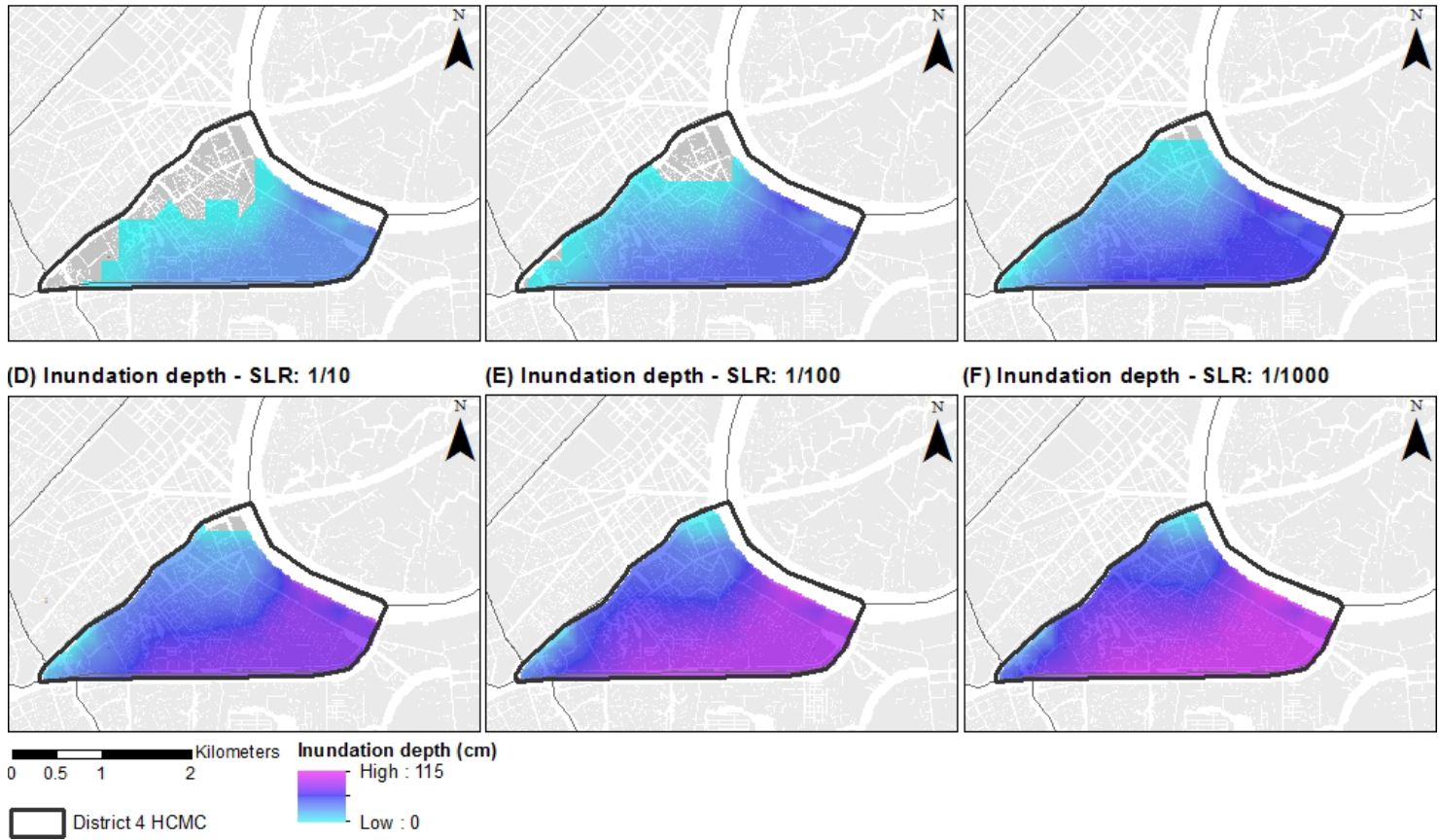

Figure 5. Modelled inundation depths for different return periods for two sea-level scenarios. The top figures (A, B, and C) result from using the baseline sea-level scenario, and the bottom figures $(\mathbf{D}, \mathbf{E}$, and $\mathbf{F})$ result from using the sea-level rise scenario.

Table 2. Costs for different adaptive measures per unit.

\begin{tabular}{llll}
\hline Measure & Construction* & Yearly maintenance & Source \\
\hline Levee & USD 9.9-27 M per km & USD 2400-100 000 per km & FIM (2013b), Aerts et al. (2013) \\
Super levee & USD 29.4 M per km, or & USD 4800 per km & Aerts et al. (2013), FIM (2013b) \\
Sand & USD 14.60-67.63 per m & 0 & FIM (2013b), van Hussen (2013) \\
Wet-proofing, 3 m & USD 200-9271 per house & 0 & Survey this study, Aerts et al. (2013), \\
& & & Zevenbergen et al. (2007) \\
Dry-proofing, 1 m & USD 500-9361 per house & 0 & Survey this study, Aerts al. (2013) \\
& 465 EUR per m ${ }^{2}$ & 0 & Kreibrich et al. (2009) \\
\hline
\end{tabular}

*Prices in USD 2013.

factor of 2.72 was used to multiply cost estimates of a normal levee, which was established by FIM (2013b).

\subsection{Benefit-cost analysis}

The effect of the strategies described in Sect. 2.4 is calculated for combinations of the two sea-level scenarios and the two land-use scenarios. The reduced flood risk (EAD) is the benefit of the strategy, and is used in the benefit-cost analysis (BCA). In particular, for each strategy the benefit/cost ratio (B / C ratio) and the net present value (NPV) are estimated, using

$\mathrm{NPV}=\sum_{t=1}^{T} \frac{\left(B_{t}-C_{t}\right)}{(1+r)^{t}}$ where $B_{t}$ is the benefit of a flood risk management strategy in year $t, C_{t}$ its cost, $r$ is the social discount rate, and the investment horizon is $T$ years. The benefit in year $t$ in this context is the avoided flood damage in year $t$, and the cost includes the initial investments or construction costs and yearly maintenance costs. A positive NPV thus indicates that the sum of the discounted benefits exceeds the sum of the discounted costs over time, which implies that a strategy is beneficial in economic terms. A related indicator of economic efficiency of a flood risk management strategy is the $\mathrm{B} / \mathrm{C}$ ratio:

$\mathrm{B} / \mathrm{C}$ ratio $=\sum_{t=1}^{T} \frac{\left(B_{t}\right)}{(1+r)^{t}} / \sum_{t=1}^{T} \frac{\left(C_{t}\right)}{(1+r)^{t}}$.

If NPV $>0$, then the $\mathrm{B} / \mathrm{C}$ ratio $>1$. Both indicators are provided here since while the $\mathrm{B} / \mathrm{C}$ ratio shows the economic 
efficiency in terms of relative benefits per dollar invested in a strategy, the NPV provides the amount of net economic benefits that a strategy generates.

Several of the studied adaptation strategies are designed to protect the city from flooding far into the future, and the benefits of these strategies will occur for the whole period. The corresponding investments thus are also made for the long term. We take this long term into account in the B / C analysis by calculating cost and benefits with a time horizon until 2100. All BCAs are conducted over an investment horizon which starts in year $2013(t=0)$, and ends in 2100 after 87 years $(T=87)$.

An important variable is the social discount rate $r$, which reflects the opportunity costs of public investments, and is especially important in BCAs of projects with a long time horizon. It is an uncertain exogenously determined parameter. A broad range of discount rate values has been used in BCAs of investments by the public sector. We use the discount rate of $5 \%(r=0.05)$, as prescribed by the National Bank of Vietnam. However, the discount rates used in evaluating flood risk management strategies with a very long time horizon are debated. Relatively high rates have the effect that monetary values far in the future receive a very small weight in estimating their present value (and the NPV). The international discussion moves towards the use of a lower discount rate between $2 \%$ and $4 \%$ for these types of projects (Ministerie van Financiën, 2011; EPA, 2010). Hence, we also include an analysis using a discount rate of $2.5 \%$.

\section{Results and discussion}

\subsection{Current and future flood risk}

Inundation depths for three return periods for District 4 are shown in Fig. 5. These are based on two sea-level scenarios: baseline and SLR. The figure shows that the southeastern part of the case-study area has the highest inundation depths, and the northern part has the lowest. The inundated area increases when looking at the baseline floods with return periods of $1 / 10,1 / 100$ and $1 / 1000$. For floods with these return periods using the SLR +30 scenario, we see that the inundation depth increases, as already at the $1 / 10$ flood return period the whole district is flooded. The $1 / 10$ flood, using the SLR +30 scenario is higher than the $1 / 1000$ flood using the baseline scenario. The maximum depth for the $1 / 1000$ flood using the $\mathrm{SLR}+30$ scenario is $1.15 \mathrm{~m}$.

Figure 6 shows the distribution of damage over the casestudy area. This map is a combination of inundation depths, and the sensitivity and value of the land-use type. The damage shows a high correlation with inundation depths. In the southeastern part of the case-study area, different land uses can be distinguished in Fig. 6, as there is a difference in damage in cells which are close to each other, and hence have comparable inundation depths. The area directly bordering the Saigon River shows lower damage. This is due to the land use, which is industrial (harbour) and less sensitive to flooding, and has a lower value than that of residential land use.

Figure 7 shows for District 4 the change in flood damage for floods with different annual probabilities, and for future land use (LU2025) due to increasing population growth, a sea-level rise of $30 \mathrm{~cm}(\mathrm{SLR}+30)$, and the combination of both developments. The EAD for the current ("baseline") land use (LU2005) and sea level is USD 0.31 million per year, increasing to USD 0.37 million per year for the land use of 2025. This increases to USD 0.68 million per year when taking into account SLR, and up to USD 0.78 million per year when taking into account both future scenarios of land use and SLR. The rising sea level has a larger effect on the EAD than the socio-economic developments, with an increase of $112 \%$ and $115 \%$, compared with $15.5 \%$ and $17.1 \%$.

\subsection{Effect of damage reducing strategies}

Table 3 shows the results of various calculations for the five flood management strategies, in combination with the landuse scenarios and sea-level scenarios. The strategies wetproofing (S2) and dry-proofing (S3) show a reduction in theEAD from $20 \%$ to $100 \%$ compared with the baseline for all combinations of scenarios. S2 has the smallest reducing effect of $20 \%$ on the EAD, while S3 reduces the EAD on average by $95 \%$. Increasing the elevation (S4) to $2.11 \mathrm{~m}$ a.s.l. reduces damage by $100 \%$ for the current sea level, and by $78 \%$ when including SLR, with an EAD of only USD 0.155 million. The other strategies (S1, S4 and CAS) reduce EAD by $100 \%$ for all scenarios.

\subsection{Benefits and costs of different types of strategies}

The benefits and costs of the different strategies in combination with land-use and sea-level scenarios, and for the two discount rates of $5 \%$ and $2.5 \%$, are listed in Table 3. The outcomes of all strategies have the same trend when varying land-use and sea-level scenarios. The LU2025 represents socio-economic development, which leads to an increase in assets exposed to flooding, compared with the LU2005, leading to higher EADs. The reduction in the EAD as a result of the adaptation strategies is considered to be a benefit, hence leading to a higher NPV, and a higher B / C ratio for the LU2025 calculations compared with the LU2005. For example the strategy S2 in combination with LU2005, the current sea level, and a discount rate of $5 \%$ results in an EAD of USD 0.252 million, with an NPV of USD -5.01 million, and a $\mathrm{B} / \mathrm{C}$ ratio of 0.330 . When the land-use scenario 2025 is used the EAD increases to USD 0.295 million, with an NPV of USD -4.68 million, and a B / C ratio of 0.375 . When SLR is included, the extent of the flood and flooding depths increase (Fig. 5) compared with the calculations without SLR. The EAD of a calculation with SLR is higher 


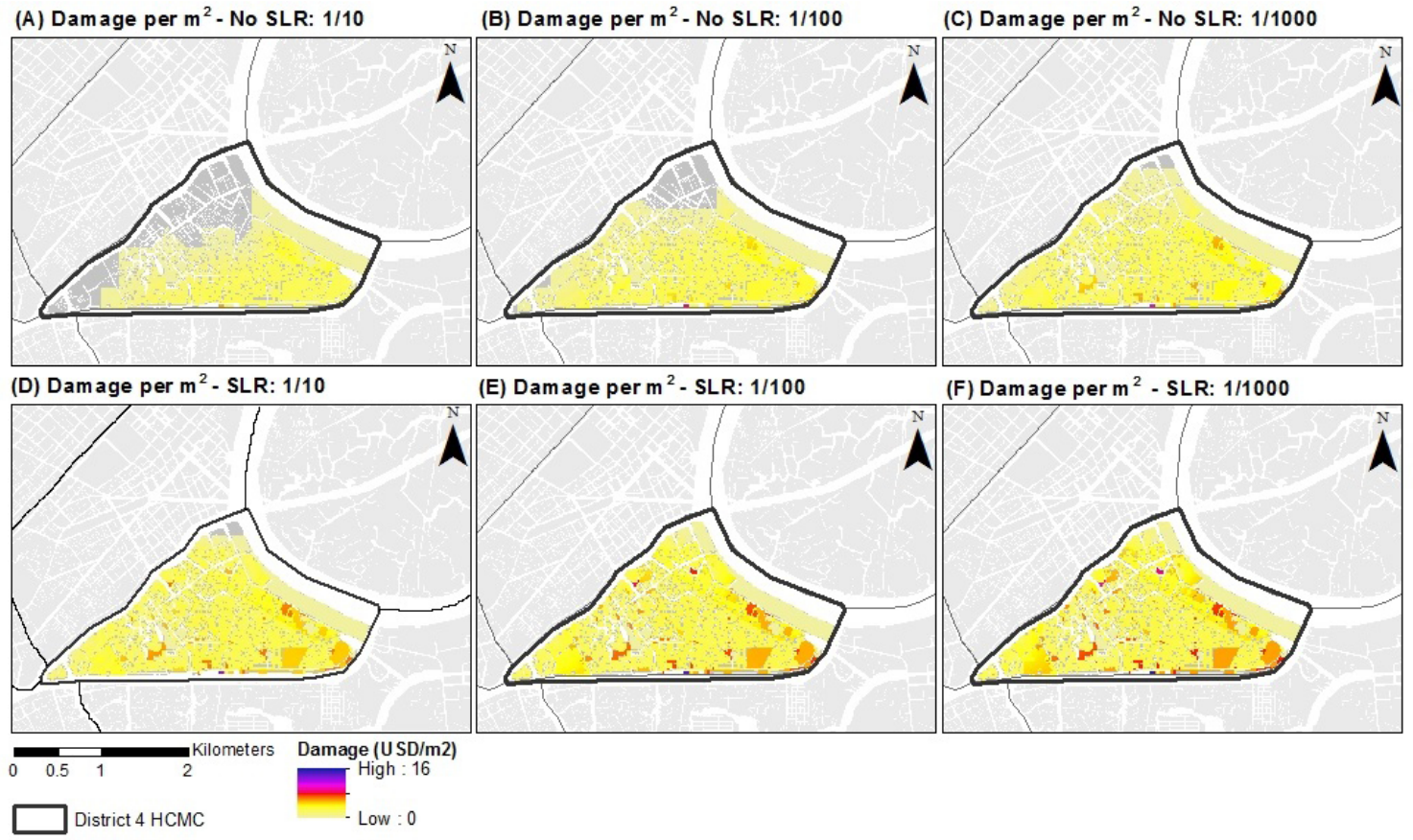

Figure 6. Damage occurring for floods with different return periods, the top figures (A, $\mathbf{B}$ and $\mathbf{C})$ result from using the baseline sea-level scenario, and the bottom figures $(\mathbf{D}, \mathbf{E}$, and $\mathbf{F})$ result from using the sea-level rise scenario.

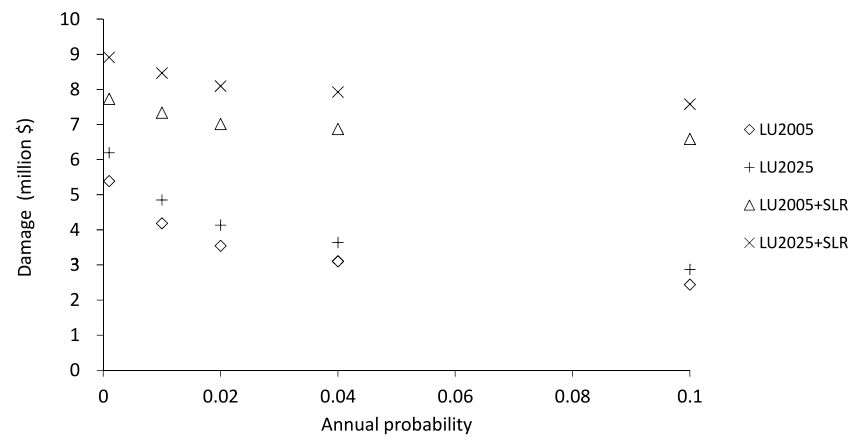

Figure 7. Annual probability and damage curves for different combinations of land-use and sea-level scenarios.

than a calculation without SLR, also improving the NPV and $\mathrm{B} / \mathrm{C}$ ratio for the damage-reducing strategies. When combining LU2005 with SLR for the strategy S2 for example, the EAD increases further to USD 0.541 million, with an NPV of USD -2.18 million, and a B / C ratio of 0.709 . When considering the combination LU2025 and SLR the EAD increases further to USD 0.624 million, with an NPV of USD -1.53 million, and a $\mathrm{B} / \mathrm{C}$ ratio of 0.796 . Table 3 and Fig. 7 show that sea-level rise has a larger effect on the EAD than land-use change.

The discount rate has an even higher influence on the costeffectiveness, with the NPV and B / C ratio increasing substantially when using the lower discount rate of $2.5 \%$. For most strategies the costs are made in the first years, and the benefits will continue to occur until 2100. Due to the lower discount rate, these benefits are valued higher, even when they occur in the more distant future. For the strategies which need yearly maintenance - ring dike (S1) and CAS (S5) - the effect of varying the discount rate is less, as the maintenance costs occurring in the future also change in the same way as the benefits.

Comparing the strategies we see that $\mathrm{S} 1, \mathrm{~S} 4+2.53$, $\mathrm{S} 4+3.37$, and S5 have a negative NPV for all combinations of scenarios and discount rates. This means that given the costs (implementation and maintenance) and benefits (reduced direct damage of flooding) considered in this study, it is not economically efficient to implement these measures. The strategies $\mathrm{S} 2, \mathrm{~S} 3$, and $\mathrm{S} 4+2.11 \mathrm{~m}$ have a positive NPV, and a B / C ratio of above 1 for the SLR scenarios in combination with a $2.5 \%$ discount rate.

As mentioned, under current climate, none of the strategies is cost effective. When comparing the strategies, S2 (wetproofing) is the cheapest strategy and has the best NPV values under the baseline circumstances, though still negative ( -3.05 using a $2.5 \%$ discount rate). However, under baseline circumstances $\mathrm{S} 4+2.11 \mathrm{~m}$ has a better B / C ratio as it reduces $\mathrm{EAD}$ more than $\mathrm{S} 2$, apparently compensating for the higher investment costs. The other strategies perform even less than these two strategies. The same applies for the combination of the base line sea level and LU2025, or the combined SLR+30 and LU2025 while using a $5 \%$ discount rate. 
Table 3. Total costs, EADs and NPVs in USD million and BCA ratios for different flood management strategies.

\begin{tabular}{|c|c|c|c|c|c|c|c|c|}
\hline \multicolumn{9}{|c|}{ Adaptation strategies $2013-2100$} \\
\hline & $\begin{array}{l}\text { S1: Ring dike } \\
(2 \mathrm{~m}) \\
\text { Implementation } \\
2025-2030\end{array}$ & $\begin{array}{l}\text { S1: Ring dike } \\
(2 \mathrm{~m}) \\
\text { Implementation } \\
2013-2018\end{array}$ & $\begin{array}{l}\text { S2: Wet- } \\
\text { proofing }(3 \mathrm{~m})\end{array}$ & $\begin{array}{l}\text { S3: } \quad \text { Dry- } \\
\text { proofing }(1 \mathrm{~m})\end{array}$ & $\begin{array}{l}\text { S4: Elevating } \\
(2.11 \mathrm{~m})\end{array}$ & $\begin{array}{l}\text { S4: Elevating } \\
(2.53 \mathrm{~m})\end{array}$ & $\begin{array}{l}\text { S4: Elevating } \\
(3.37 \mathrm{~m})\end{array}$ & $\mathrm{S}: 5$ CAS $(2 \mathrm{~m})$ \\
\hline $\begin{array}{l}\text { Investment costs } \\
\text { (mln USD) }\end{array}$ & 89 & 89 & 7.5 & 19 & 31 & 65 & 116 & 129 \\
\hline $\begin{array}{l}\text { Yearly maintenance costs } \\
\text { (mln USD) }\end{array}$ & 0.021 & 0.021 & 0 & 0 & 0 & 0 & 0 & 0.026 \\
\hline \multicolumn{9}{|c|}{ Current sea level } \\
\hline EAD LU05 (mln USD)* & 0 & 0 & 0.252 & 0.010 & 0 & 0 & 0 & 0 \\
\hline $\begin{array}{l}\text { NPV (mln USD) using high } \\
(5 \%) \text { and low }(2.5 \%) \text { dis- } \\
\text { count rate and correspond- } \\
\text { ing B / C ratio, LU05 }\end{array}$ & $\begin{array}{l}-39.40(0.124) \\
-48.91(0.233)\end{array}$ & $\begin{array}{l}-70.96(0.125) \\
-65.44(0.233)\end{array}$ & $\begin{array}{l}-5.01(0.330) \\
-3.05(0.592)\end{array}$ & $\begin{array}{l}-23.67(0.326) \\
-15.30(0.578)\end{array}$ & $\begin{array}{l}-13.79(0.410) \\
-7.56(0.717)\end{array}$ & $\begin{array}{l}-39.80(0.194) \\
-37.24(0.354)\end{array}$ & $\begin{array}{l}-78.59(0.109) \\
-81.52(0.190)\end{array}$ & $\begin{array}{l}-107.47(0.086) \\
-103.76(0.161)\end{array}$ \\
\hline EAD LU25 (USD) ${ }^{\mathrm{a}}$ & 0 & 0 & 0.295 & 0.017 & 0 & 0 & 0 & 0 \\
\hline $\begin{array}{l}\text { NPV (mln USD) using high } \\
(5 \%) \text { and low }(2.5 \%) \text { dis- } \\
\text { count rate and correspond- } \\
\text { ing B / C ratio, LU25 }\end{array}$ & $\begin{array}{l}-38.45(0.145) \\
-46.51(0.261)\end{array}$ & $\begin{array}{l}-69.40(0.145) \\
-62.25(0.270)\end{array}$ & $\begin{array}{l}-4.68(0.375) \\
-2.39(0.681)\end{array}$ & $\begin{array}{l}-22.24(0.366) \\
-12.44(0.657)\end{array}$ & $\begin{array}{l}-12.31(0.473) \\
-4.47(0.832)\end{array}$ & $\begin{array}{l}-38.21(0.224) \\
-34.16(0.394)\end{array}$ & $\begin{array}{l}-77.11(0.125) \\
-78.44(0.221)\end{array}$ & $\begin{array}{l}-105.92(0.100) \\
-100.58(0.186)\end{array}$ \\
\hline \multicolumn{9}{|c|}{ Sea level $+30 \mathrm{~cm}$} \\
\hline EAD LU05 (mln USD)* & 0 & 0 & 0.541 & 0.031 & 0.155 & 0 & 0 & 0 \\
\hline $\begin{array}{l}\text { NPV (mln USD) using high } \\
(5 \%) \text { and low }(2.5 \%) \text { dis- } \\
\text { count rate and correspond- } \\
\text { ing B / C ratio, LU05 }\end{array}$ & $\begin{array}{l}-33.00(0.266) \\
-32.84(0.478)\end{array}$ & $\begin{array}{l}-59.30(0.269) \\
-42.67(0.500)\end{array}$ & $\begin{array}{l}-2.18(0.709) \\
\mathbf{2 . 0 2}(\mathbf{1 . 2 7 0})\end{array}$ & $\begin{array}{l}-10.91(0.689) \\
\mathbf{8 . 0 4}(\mathbf{1 . 2 2 2})\end{array}$ & $\begin{array}{l}-7.55(0.677) \\
4.91(1.184)\end{array}$ & $\begin{array}{l}-33.55(0.321) \\
-24.78(0.560)\end{array}$ & $\begin{array}{l}-72.34(0.179) \\
-69.05(0.314)\end{array}$ & $\begin{array}{l}-105.75(0.101) \\
-92.00(0.256)\end{array}$ \\
\hline EAD LU25 (mln USD)* & 0 & 0 & 0.624 & 0.044 & 0.170 & 0 & 0 & 0 \\
\hline $\begin{array}{l}\text { NPV (mln USD) using high } \\
(5 \%) \text { and low }(2.5 \%) \text { dis- } \\
\text { count rate and correspond- } \\
\text { ing B / C ratio, LU } 25\end{array}$ & $\begin{array}{l}-31.14(0.308) \\
-28.17(0.552)\end{array}$ & $\begin{array}{l}-57.46(0.292) \\
-37.89(0.556)\end{array}$ & $\begin{array}{l}-1.53(0.796) \\
\mathbf{3 . 2 4}(\mathbf{1 . 4 4 4 )}\end{array}$ & $\begin{array}{l}-8.13(0.768) \\
13.26(1.376)\end{array}$ & $\begin{array}{l}-5.68(0.757) \\
\mathbf{9 . 3 8}(\mathbf{1 . 3 5 2})\end{array}$ & $\begin{array}{l}-31.67(0.358) \\
-20.31(0.640)\end{array}$ & $\begin{array}{l}-70.48(0.201) \\
-64.58(0.358)\end{array}$ & $\begin{array}{l}-93.88(0.201) \\
-76.21(0.384)\end{array}$ \\
\hline
\end{tabular}

* The lifetime of the measures is assumed to be 87 years.

Only for the combination SLR+30, LU2025, and discount rate $2.5 \%$ do some strategies become cost effective. Strategy S3 (dry-proofing), has the best result in terms of NPV (USD 13.26 million) and B / C ratio (1.376). Compared to the two other strategies with positive NPVs, S2, and $\mathrm{S} 4+2.11 \mathrm{~m}, \mathrm{~S} 3$ results in a higher reduction in damage. Our results indicate that elevating to a level of $2.11 \mathrm{~m}$ a.s.l. is economically more efficient than elevating to $2.53 \mathrm{~m}$, even though the latter reduces the EAD to zero. This means that the costs of the extra elevation outweigh the risk reduction as flood levels above $2.11 \mathrm{~m}$ a.s.l. only happen rarely.

For the adaptation strategy S1, Ring dike, we also explored the effect of delayed implementation, assuming start of work in 2025 and finalization in 2030 as opposed to 2013-2018. This would result in an increase in cost effectiveness (i.e. higher NPV and B / C ratio), though they will remain smaller than zero. For the scenario LU2025 and SLR+30 in combination with a discount rate of $5 \%$ this leads to a NPV of USD -31.14 million and a $\mathrm{B} / \mathrm{C}$ ratio of 0.308 , compared to a NPV of USD -57.46 million and B / C of 0.292 for the original calculation. Using a discount rate of $2.5 \%$ the NPV is USD -28.17 million and the $\mathrm{B} / \mathrm{C}$ ratio is 0.552 , compared to a NPV of USD 37.89 million and $\mathrm{B} / \mathrm{C}$ ratio of 0.556 .

To explore the effect of a very high discount rate on the economic performance, we calculated the outcomes for the S1 strategy in combination with SLR+30 and LU2025 using a discount rate of $9 \%$. This is the percentage the Vietnamese government currently pays on its 10 -year bonds. The resulting NPV is USD -64.44 million and the B / C ratio is 0.147 . These values are well below the results using a discount rate of $5 \%$. This is mainly because the investments are made in the near future, and the benefits occur over a longer period into the future.

\section{Discussion of results}

\subsection{Comparison of results}

The results of this study indicate that flood damage will increase as a result of socio-economic change (15.5-17.1\%) in the shorter term (see also Bouwer, 2011). However, in the longer term, the major increase in flood damage is caused by rising sea levels (112-115\%). This is in line with de Moel et al. (2014) who found a doubling of flood risk due to climate 
change for the case of Rotterdam in the Netherlands, and with Poussin et al. (2012) who report an increase in flood risk between $97 \%$ and $185 \%$, for a similar projection year 2050. Note, however, that the projection years for climate change and sea-level rise (2050) are different from socioeconomic change (2025), and Storch and Downes (2011) have concluded that spatial developments for the whole of HCMC (including new urban areas) until 2025 have a larger impact on flood damage than projected SLR. Our study, however, focused on an existing urban area, for which apparently socio-economic developments are less important than SLR. Additional analysis with land-use scenarios for 2050 would allow for an improved analysis of the relative influence of future projections on flood risk.

The EAD for District 4 for the baseline situation is USD 0.315 million per year, or USD 1146 per hectare per year. The FIM (2013a) study, which evaluated the impacts of flooding on HCMC and the wider region around it, reported an EAD of USD 1144 million per yr, or USD 17595 per hectare per year. One reason for the higher EAD estimate by FIM (2013a) is that they assume a maximum damage for urban houses of USD 1377 per $\mathrm{m}^{2}$, which is much higher than the USD 28.30 per $\mathrm{m}^{2}$ applied in this study. Empirical data from the Thailand flood of 2011 show that our estimate is quite realistic. A study by the World Bank (2012) indicates that the maximum damage for a house in Bangkok is USD 27.10 per $\mathrm{m}^{2}$, which is comparable to our estimate for buildings in HCMC. When comparing the maximum damage with existing European studies (e.g. de Moel et al., 2014; te Linde et al., 2011; Kreibich et al., 2005), we see that the absolute numbers are obviously much lower in HCMC. For example, the maximum damage for houses in the Netherlands is EUR 1600 per $\mathrm{m}^{2}$ (USD 2176 per $\mathrm{m}^{2}$ ) (de Moel et al., 2014). However, when taking the different gross domestic products of Vietnam and the Netherlands into account, we see that the maximum damage per house for the Netherlands becomes USD 182 per $\mathrm{m}^{2}$.

The adaptation strategies achieve a reduction in EAD of between $20 \%$ and $100 \%$, compared with the baseline. Wetproofing has the smallest effect of $20 \%$, the other measures reduce the EAD by between $75 \%$ and $100 \%$. These are larger reductions than for instance the measures studied by Poussin et al. (2012), who found a reduction of dry-proofing of $40 \%$. This is confirmed by Kreibich et al. (2005), who surveyed 1248 vulnerable households in the Elbe basin in Germany, and found that wet-proofing (flood-adapted interior fitting and the installation of heating and electrical utilities in higher storeys) reduced the mean damage ratio for buildings by $53 \%$ and $36 \%$, respectively. These studies, however, concerned areas where high water depths can occur, in which case flood-proofing of houses ceases to be effective. In our case, inundation levels are generally between $2 \mathrm{~cm}$ and $115 \mathrm{~cm}$ for the entire area. This is more comparable to a similar case in the "outer dikes" areas of Rotterdam, the Netherlands, where de Moel et al. (2014) found a reduction of $29 \%$ for wet-proofing, $61 \%$ for dry-proofing, and $50 \%$ for increasing the elevation by $50 \mathrm{~cm}$.

Regarding the results of the evaluation of the strategies on economic criteria, the NPV and the B / C ratio, we see that most strategies have a negative NPV under the different combinations of scenarios. Only S2, S3, S4 + 2.11 have positive values when using the combination of the SLR scenario and the land-use scenario for 2025 . It should be noted, however, that the costs for damage to goods outside the house, the cleaning of the house and property, and nuisance were not included in these analyses. A sensitivity analysis was carried out for the strategy S1 (ring dike) using a discount rate of $2.5 \%$, SLR30+, and land-use scenario 2025. When doubling, and tripling the damage cost, the corresponding NPVs changed from USD -37.89 million, to USD 7.06 million, and USD 55.89 million, respectively. The $\mathrm{B} / \mathrm{C}$ ratios, similarly, appear to be quite sensitive, changing from 0.556 to 1.083 , and 1.655 , respectively. When applying a varying discount rate of $2.5 \%, 5 \%$, and $9 \%$ on $\mathrm{S} 1$, the corresponding NPVs were USD -37.89 million, USD -57.46 million, and USD - 64.44 million. The B / C ratios, similarly, appear to be quite sensitive, with values of $0.556,0.292$, and 0.147 , respectively (e.g. Hallegatte, 2006).

The outcomes of the EAD of this study are probably underestimations, as land-use change is included only until 2025, and sea-level rise until 2050. Both trends probably will continue toward 2100 . The sea-level rise projections for HCMC are 65 to $100 \mathrm{~cm}$ in 2100 (MONRE, 2009), adding another 35 to $70 \mathrm{~cm}$ to the sea-level rise scenario we used in this study. Unfortunately, these flood maps were not available for this study. We also did not account for change in storminess, which is expected to increase for HCMC according to experts. The expected changes between 2050 and 2100 will lead to an increase in the EAD, as there will be an increase in exposed assets and an increase in the flood depth. If the EAD increases, this will lead to increased benefits in the $\mathrm{B} / \mathrm{C}$ analysis, as prevented damage is a benefit for the strategies. In a future evaluation these longer-term effects should be included.

\subsection{Strengths and limits of applied methods}

The approach of the research included different steps, from hydrologic modelling, via participatory development of adaptation strategies, to a benefit-cost analysis. The inclusion of stakeholders and local participants in this process is relatively novel in flood risk management in HCMC, and has resulted in improved access to local information, and the development of adaptation strategies tailored to local circumstances. This effect is comparable to the results found by Douma et al. (2014). This stakeholder approach was also chosen to increase flood awareness, and the Vietnamese participants did indeed report to the involved Dutch experts that they have gained knowledge on these topics. However, we have not systematically measured the learning effect, as 
has been done by Arciniegas et al. (2011). The topic of climate change has gained importance in HCMC. At the end of the VCAPS project a climate change bureau has been established in HCMC. People from different departments jointly work in this bureau to further develop and implement adaptation measures. Several of these people were involved in the VCAPS project, including the vice managing director of the climate change bureau. Also, a follow-up project to explore how adaptation could be included in the Vietnamese decision-making started in 2014, and this project uses District 4 as a pilot case. This indicates that the topic of climate change has been adopted by the policy makers and civil servants in HCMC.

By means of the survey, we gathered household level data on the occurrence of flood damage in relation to water depths: this is the first survey which has gathered these data in HCMC. However, the survey data showed quite a large variation in damage per square metre. For houses of more than two floors high, the average maximum damage is USD 28.30, and, for houses up to two floors, the average maximum damage is USD 7.46. Other studies show that self-reporting on, for example, damage or time spent on certain activities is difficult for respondents (e.g. Lasage et al., 2013; Poussin et al., 2012). Unfortunately, other reports on occurred damage are, to our knowledge, not available. Such information could be used to validate survey results. Future research would benefit if flood damage were to be registered by, for instance, the government. We did not include casualties due to flooding in our analysis. It is recommended to study whether causalities will increase due to climate change.

Cities such as Tokyo, Shanghai, Bangkok and Jakarta are confronted with land subsidence, which increases flood risk substantially (Nicholls and Cazenave, 2010; Ward et al., 2011a). This is also a major issue for HCMC (ADB, 2010; FIM, 2013a). Unfortunately, data on subsidence were not available, hence are not included in the analysis. However, the strategies Ring dike, CAS and Elevating all areas to a level of $3.37 \mathrm{~m}$ a.s.l. are relatively robust, since the maximum simulated water levels are lower than the protection standards of those strategies. Hence, the proposed strategies can be considered robust options to cope with additional SLR and subsidence of circa $0.84 \mathrm{~m}$. It is recommended, however, that the issue of subsidence be addressed in future studies (Nicholls and Cazenave, 2010).

\subsection{Policy implications}

This study has provided relevant information on vulnerable people and assets at risk to policy makers in a participatory approach. It also has shown the effectiveness of several adaptation strategies to reduce risk. Bubeck et al. (2011) conclude that these are the first steps to raise awareness, which is needed, in order to take effective action against the changing flood risk. For instance, the information can be used in the implementation of the Vietnamese government's national target programme to respond to climate change (DONRE, 2007). It appears that including long-term projections in policy planning is difficult, and this study serves as an example of the net benefits of addressing long-term changes to shortterm investments. We show that most of the proposed strategies have a negative NPV, and these NPVs improve over the longer term when risks are increasing. We also show that NPVs are dependent on the benefits, which are related to preventing damage. If the damage is twice as high as we have used in our analysis, most strategies will have a positive NPV. Also, if other benefits occur with the strategies, like for example improved spatial quality, these could lead to more positive NPVs. Future research should also look into the division of costs related to the different strategies, and who should pay. It will be an apportionment between individual households, the city, national government and private enterprises. Official Development Assistance (ODA) could also contribute to the investments, comparable to the JICA drainage master plan (FIM, 2013a). HCMC will be confronted with flooding more often as a result of sea-level rise, which, together with its economic growth (and hence a growing exposure), will increase the sense of urgency to act (VCAPS, 2013). This trend will lead to a reduced acceptance of the nuisance and damage occurring during flood events by the population, as has been shown to occur in, for example, European cities and regions (Becker et al., 2014). Households are already taking measures to reduce their exposure and sensitivity to flooding; in particular, those households with enough means are investing in elevating the level of the ground floor. Moreover, almost every household has taken measures to wet-proof their property. For this type of measure it should be taken into account that if the investment costs are paid for by the private household, the poor will remain more vulnerable than households which have the means to invest. If wet-proofing becomes a part of the adaptation strategy of HCMC, this (side) effect should be included. In addition, the elevation of roads is being implemented in several locations of District 4, despite its costs (personal observations). For the final decision by the government of HCMC as to which strategy is the best to implement, other information besides NPV and B / C ratio will be used, like technical, social and governance availability and capacity: for instance, the impact and disturbance a strategy has on the residents, or the need for coordination by the government. For further study, especially when it pertains the whole city, including the wetlands, it is recommended to include valuation assessment of other costs and benefits, such as impacts on environmental and societal values. This can be done using different techniques (Brouwer and van Ek, 2004) or by using multi-criteria analysis, which makes it possible to include non-monetary units in the evaluation. The public consensus might vary between the strategies, influencing their chance of successful implementation. 


\section{Conclusions}

On the basis of the results of this study, we conclude that the current flood risk of District 4 in Ho Chi Minh City, and expressed as Estimated Annual Damage (EAD) is USD 0.31 million per year. This risk is projected to increase over the coming years up to USD 0.78 million per year. Sea level rise has a larger effect on the expected annual damage than socio-economic developments, with increases in EAD of a maximum of $115 \%$ and $17 \%$, respectively. The damage mainly concerns residential buildings, which cover most of the case-study area. Residential buildings are divided into two classes: buildings with less than two floors, and those of two floors and more. For residential buildings, we have established new stage-damage curves based on household survey data. In future research in densely populated urban areas, it would be advisable to validate the self-reported damage with actual damage data. This would improve the reliability of the survey results. The adaptation strategies resulting from the participatory process are not very different from other studies. However, the approach we followed has improved access to local information and documentation, and the capacity to deal with climate change and adaptation of the people involved has increased. Most of the adaptation strategies evaluated in this study have a negative NPV under all scenarios. The strategies Wet-proofing, Dry-proofing, and Elevating to $2.11 \mathrm{~m}$ a.s.l., are effective for the sea-level rise scenario in combination with the high socio-economic scenario and a discount rate of $2.5 \%$. It should be noted that the strategies Ring dike, Elevating to $3.37 \mathrm{~m}$ a.s.l., and CAS prevent flooding up to a relative sea-level rise of $1.14 \mathrm{~m}$ compared with the baseline situation, indicating their even longer time horizon. Future research should assess whether a positive NPV is reached when flood depths increase. We believe that our approach is suitable for assessing changing flood risks in urban areas, which are exposed to coastal flooding. In Asia alone $24 \%$ of the cities with more than 1 million inhabitants are located in low-elevation coastal zones (IIED, 2009), indicating a high vulnerability to flooding. In these cities this approach could be used to assess the risk, and evaluate adaptive measures.

Acknowledgements. The authors would like to thank Mr. Nga, Hoang Vo, Duy Dinh Van, Hang Tran, and Nguyen Nguyen for their support in the field and in accessing data, and the Dutch partners of the VCAPS project for the discussions and exchange of ideas during the project. The research leading to this article is partly funded by The Dutch Ministry of Infrastructure and Environment through the VCAPS project (contract P311325) and the 7th Framework Programme through the EU FP7 project RISES-AM (grant agreement no. 603396) and the FP7 project TURAS (grant agreement no. 282834) data have been provided from a survey funded by the Viet Nam National University Ho Chi Minh City under grant number A2013-48-01 and the Steering Center of Flood Control Ho Chi Minh City.
Edited by: H. Kreibich

Reviewed by: P. Schmidt-Thomé and two anonymous referees

\section{References}

ADB, Asian Development Bank: Ho Chi Minh City - Adaptation to climate change: Summary report, Mandaluyong City, Asian Development Bank, ISBN 978-92-9092-108-0, 2010.

Adikari, Y., Osti, R., and Noro, T.: Flood-related disaster vulnerability: an impending crisis of megacities in Asia, J. Flood Risk Manage., 3, 185-191, 2010.

Aerts, J. C. J. H. and Botzen, W. J. W.: Flood-resilient waterfront development in New York City: Bridging flood insurance, building codes, and flood zoning, Ann. N.Y. Acad. Sci., 1227, 1-82, doi:10.1111/j.1749-6632.2011.06074.x, 2011.

Aerts, J. C. J. H., Botzen, W. J. W., de Moel, H., and Bowman, M.: Cost estimates for flood resilience and protection strategies in New York City, Ann. N.Y. Acad. Sci., 1294, 1-104, doi:10.1111/nyas.12200, 2013.

Apel, H., Aronica, G. T., Kreibich, H., and Thieken, A. H.: Flood risk analyses - how detailed do we need to be?, Nat. Hazards, 49, 79-98, 2008.

Arciniegas, G. A., Janssen, R., and Omtzigt, N.: Map-based multicriteria analysis to support interactive land-use allocation, Int. J. Geogr. Inf. Sci., 25, 1931-1947, 2011.

Becker, G., Aerts, J. C. J. H., and Huitema, D.: Influence of flood risk perception and other factors on risk-reducing behaviour: a survey of municipalities along the Rhine, J. Flood Risk Manage., 7, 16-30, doi:10.1111/jfr3.12025, 2014.

Botzen, W. J. W., Aerts, J. C. J. H., and de Moel, H.: Cost estimates of Strategy Open Resilient City, Chapter 2 in: Cost estimates for flood resilience and protection strategies in New York City, edited by: Aerts, J. C. J. H, Botzen, W. J. W., de Moel, H., and Bowman, M., Ann. N.Y. Acad. Sci., 1294, 1-104, doi:10.1111/nyas.12200, 2013.

Bouwer, L. M.: Have disaster losses increased due to anthropogenic climate change?, Bull. Am. Meteorol. Soc., 92, 39-46, doi:10.1175/2010BAMS3092.1, 2011.

Bouwer, L. M., Bubeck, P., and Aerts, J. C. J. H.: Changes in future flood risk due to climate and development in a Dutch polder area, Global Environ. Change, 20, 463-471, doi:10.1016/j.gloenvcha.2010.04.002, 2010.

Brouwer, R. and van Ek, R.:Integrated ecological, economic and societal impact assessment of alternative flood protection measures in the Netherlands, Ecol. Econom., 50, 1-2-1-21, 2004.

Bubeck, P. and de Moel, H.: Sensitivity analysis of flood damage calculations for the river Rhine, 32 Report IVM, DG Waters, The Netherlands, 2010.

Bubeck, P., de Moel, H., Bouwer, L. M., and Aerts, J. C. J. H.: How reliable are projections of future flood damage?, Nat. Hazards Earth Syst. Sci., 11, 3293-3306, doi:10.5194/nhess-11-32932011, 2011.

CDWR, California Department of Water Resources: North Delta Flood Control and Ecosystem Restoration Project Administrative Draft EIR - Tidal and Flood Hydraulic Modelling, 2006.

CVCP, Congress of Vietnam Communist Party: Vietnam's socioeconomic development strategy for the period of 2011-2020, 18 pp., 2011. 
Dawson, R. J., Ball, T., Werritty, J., Werritty, A., Hall, J. W., and Roche, N.: Assessing the effectiveness of non-structural flood management measures in the Thames Estuary under conditions of socio-economic and environmental change, Global Environ. Change, 21, 628-646, doi:10.1016/j.gloenvcha.2011.01.013, 2011.

DEFRA: Developing the evidence base for flood resistance and resilience: summary report, R\&D Technical report FD2607/TR1. Environment Agency and the Department for Environment Food and Rural Affairs, London, 2008.

de Moel, H. and Aerts, J. C. J. H.: Effect of uncertainty in land-use, damage models and inundation depth on flood damage estimates, Nat. Hazards, 58, 407-425, 2011.

de Moel, H., van Vliet, M., and Aerts, J. C. J. H.: Evaluating the effect of flood damage-reducing measures: a case study of the unembanked area of Rotterdam, the Netherlands, Regional Environ. Change, 14, 895-908, doi:10.1007/s10113-013-0420-z, 2014.

DHI Water \& Environment: MIKE 11 - A modelling system for rivers and channels. Short introduction tutorial, 88 pp., 2003.

DONRE: National target program to respond to climate change, Resolution No. 60/2007/NQ-CP, Ministry of natural resources and environment, Hanoi, Vietnam, 2007.

Douma, A., Hirsch, D., Kinney, K., and Lasage, R.: Equity matters: Introducing the capabilities approach in adaptation to climate change in river basins in Ghana and Peru. Chapter 12 in: Adaptation to Climate Change through Water Resources Management: Capacity, Equity, and Sustainability, edited by: Stucker, D. and Lopez, E., Earthscan publishers, 243-263, 2014.

DPA: Draft spatial plan HCMC, 24/QĐ-TTg 6-1-2010, Department of architecture and planning, Ho Chi Minh city, Vietnam, 2010.

Duong, M. N.: Grassroots Democracy in Vietnamese Communes, Research Paper for the Centre for democratic Institutions, Research School of Social Sciences, the Australian National University, 2004.

Eckert, R., Voigt, C., and Kien, T. T.: Developing guidelines for energy and climate efficient urban structures a new planning instrument for adapting Ho Chi Minh City to the impacts of climate change, Fifth Urban Research Symposium, 2009.

EPA: Discountng Future Benefits and Costs, chapter 6 in Guidelines for preparing economic analyses, EPA 240-R-10-001United States Environmental Protection Agency, 2010.

FEMA: Homeowner's Guide to Retrofitting, 2nd Edn., US Department of Homeland Security: Federal Insurance and Mitigation Administration (FEMA), Washington, DC, available at: http://www.fema.gov/library/viewRecord.do?id=_1420, 2009.

FIM: Ho Chi Minh City Flood and Inundation Management Final report, Volume 2, Integrated flood management strategy, Haskoning-DHV, 146 pp., $2013 \mathrm{a}$.

FIM: Ho Chi Minh City Flood and Inundation Management - Final Report Volume 2: IFRM Strategy Annex 2: CBA Based on Flood Risk Approach. Haskoning-DHV, 39 pp., 2013b.

Grossi, P., Kunreuther, H., and Windeler, D.: An introduction to catastrophe models and insurance, in: Catastrophe modeling: a new approach to managing risk, edited by: Grossi, P. and Kunreuther, H., Springer Science Business Media, Inc., Boston, 2342, 2005.

Hallegatte, S.: A Cost-Benefit Analysis of the New Orleans Flood Protection System AEI-Brookings Joint Center, Washington, 2006.
Hanson, S., Nicholls, R., Ranger, N., Hallegatte, S., Corfee-Morlot, J., Herweijer, C., and Chateau J.: A global ranking of port cities with high exposure to climate extremes, Climatic Change, 104, 89-111, doi:10.1007/s10584-010-9977-4, 2011.

Hostovsky, C. and Maclaren, V.: The Role of Public Consultation in Vietnamese Waste and Other EIAs. First International Conference on Integrated Solid Waste Management in Southeast Asia, 5-6 July 2005, Siem Reap, Cambodia, 2005.

Huntjens, P., Ottow, B., and Lasage, R.: Participation in Climate Adaptation in the Lower Vam Co River Basin in Vietnam, Chapter 4 in: Action research for climate change adaptation: Developing and applying knowledge for governance, edited by: van Buuren, A., Eshuis, J., and van Vliet, M., Routeldge, London, 2014.

Huq, S., Kovats, S., Reid, H., and Datterthwaite, S.: Editorial: Reducing risks to cities from disasters and climate change, Environ. Urbanization, 19, 3-15, doi:10.1177/0956247807078058, 2007.

IIED: Population Dynamics and Climate Change, edited by: Guzmán, J. M., Martine, G., McGranahan, G., Schensul, D., and Tacoli, C., ISBN: 978-0-89714-919-8, 250 pp., 2009.

IMF: World economic outlook database April 2012, available at: www.imf.org/external/pubs/ft/weo/2012/01/weodata/index. aspx, last access: October 2013.

IPCC: Climate Change 2007: impacts, adaptation and vulnerability. Contribution of working group II to the fourth assessment report of the intergovernmental panel on climate change. Cambridge University Press, Cambridge, UK, 2007.

Jongman, B., Kreibich, H., Apel, H., Barredo, J. I., Bates, P. D., Feyen, L., Gericke, A., Neal, J., Aerts, J. C. J. H., and Ward, P. J.: Comparative flood damage model assessment: towards a European approach, Nat. Hazards Earth Syst. Sci., 12, 3733-3752, doi:10.5194/nhess-12-3733-2012, 2012.

Klijn F., Baan, P. J. A., De Bruijn, K. M., and Kwadijk J.: Overstromingsrisico's in Nederland in een veranderend klimaat, Q4290, WL|delft hydraulics, Delft, Netherlands, 2007 (in Dutch).

Koks, E. E., de Moel, H., and Koomen, E.: Comparing Extreme Rainfall and Large-Scale Flooding Induced Inundation Risk Evidence from a Dutch Case-Study, Chapter 1 in: Studies on water management issues, edited by: Kumarasamy, M., Intech, Rijeka, 3-26, 2012.

Koks, E. E, de Moel, H., Aerts, J. C. J. H., and Bouwer, L. M.: Effect of spatial adaptation measures on flood risk: study of coastal floods in Belgium, Reg. Environ. Change, 14, 413-425, doi:10.1007/s10113-013-0514-7, 2014.

Kreibich, H. and Thieken, A. H.: Coping with floods in the city of Dresden, Germany, Nat. Hazards, 51, 423-436, 2009.

Kreibich, H., Thieken, A. H., Petrow, Th., Müller, M., and Merz, B.: Flood loss reduction of private households due to building precautionary measures - lessons learned from the Elbe flood in August 2002, Nat. Hazards Earth Syst. Sci., 5, 117-126, doi:10.5194/nhess-5-117-2005, 2005.

Kron, W.: Flood risk=hazard $\mathrm{x}$ exposure $\mathrm{x}$ vulnerability, Water Int., 30, 58-68, 2002.

Lasage, R., Aerts, J. C. J. H., Verburg, P. H., and Sileshi, A. S.: The role of small scale sand dams in securing water supply under climate change in Ethiopia, Mitig. Adapt. Strateg. Glob Change., doi:10.1007/s11027-013-9493-8, accepted, 2013. 
Merz, B. and Thieken, A. H.: Flood risk curves and uncertainty bounds, Nat. Hazards, 51, 437-458, doi:10.1007/s11069-0099452-6, 2009.

Merz, B., Kreibich, H., Schwarze, R., and Thieken, A.: Review article "Assessment of economic flood damage", Nat. Hazards Earth Syst. Sci., 10, 1697-1724, doi:10.5194/nhess-10-16972010, 2010.

Meyer, V., Scheuer, S., and Haase, D.: A multicriteria approach for flood risk mapping exemplified at the Mulde river, Germany, Nat. Hazards, 48, 17-39, 2009.

Ministerie van Financiën: Reële discontovoet en risico-opslag in maatschappelijke kosten-batenanalyses, Brief aan de Tweede Kamer dd. 24 augustus, 2011.

Ministry of construction: Decision No. 04/2008/QD-BXD, Promulgating the Vietnam building code on regional and urban planning and rural residential planning, Official gazette, 1-3 April, 2008.

MONRE: Climate change sea level rise scenarios for Vietnam, Ministry of natural resources and environment, Hanoi, Vietnam, 34 pp., 2009.

MPI, Ministry of Planning and Investment: Population projections for Vietnam 2009-2049, Statistics office MPI, Hanoi, Vietnam, 320 pp., 2011.

Nicholls, R. J. and Cazenave, A.: Sea-Level Rise and Its Impact on Coastal Zones, Science, 328, 1517, doi:10.1126/science.1185782, 2010.

Nicholls, R. J., Hanson S., Herweijer C., Patmore N., Hallegatte S., Corfee-Morlot J., Château J., and Muir-Wood. R.: Ranking port cities with high exposure and vulnerability to climate extremes: exposure estimates. OECD environment working papers No. 1, ENV/WKP(2007), OECD, Paris, France, 2008.

Poussin, J. K., Bubeck, P., Aerts, J. C. J. H., and Ward, P. J.: Potential of semi-structural and non-structural adaptation strategies to reduce future flood risk: case study for the Meuse, Nat. Hazards Earth Syst. Sci., 12, 3455-3471, doi:10.5194/nhess-123455-2012, 2012.

Ranger, N., Hallegatte, S., Bhattacharya, S., Bachu, M., Priya, S., Dhore, K., Rafique, F., Mathur, P., Naville, N., Henriet, F., Herweijer, C., Pohit, S., and Corfee-Morlo, J.: An assessment of the potential impact of climate change on flood risk in Mumbai, Climatic Change, 104, 139-167, 2011.

Storch, H. and Downes, N. K.: A scenario-based approach to assess Ho Chi Minh City's urban development strategies against the impact of climate change, Cities, 28, 517-526, 2011. te Linde, A. H., Bubeck, P., Dekkers, J. E. C., de Moel, H., and Aerts, J. C. J. H.: Future flood risk estimates along the river Rhine, Nat. Hazards Earth Syst. Sci., 11, 459-473, doi:10.5194/nhess-11-459-2011, 2011.

Toyoda: Economic Impacts of Kobe Earthquake: A Quantitative Evaluation after 13 Years, Proceedings of the 5th International ISCRAM Conference - Washington, DC, USA, May 2008.

UN: World Urbanization Prospects, The 2011 revision, Department of Economic and Social Affairs, Population Division, 318 pp., 2012.

van Hussen, K.: Maatschappelijke kosten-batenanalyse hemelwaterinfiltratie in bestaand stedelijk gebied - Toetsing van klimaatadaptatiemaatregelen, Master's thesis Earth science and economics, VU University, Amsterdam, 2013.

VCAPS: Climate Adaptation Strategy for Ho Chi Minh City, Report VCAPS project, Grontmij, 126 pp., 2013.

Veerbeek, W. and Zevenbergen V.: Deconstructing urban flood damages: increasing the expressiveness of flood damage models combining a high level of detail with a broad attribute set, J. Flood Risk Manage., 2, 45-57, 2009.

Vo, P. L.: Water resources management in Ho Chi Minh City, Vietnam: An Overview, Sci. Technol. Develop., 12, 51-63, 2009.

Ward, P. J., Marfai, M. A., Yulianto, F., Hizbaron, D. R., and Aerts, J. C. J. H.: Coastal inundation and damage exposure estimation: a case study for Jakarta, Nat. Hazards, 56, 899-916, doi:10.1007/s11069-010-9599-1, 2011a.

Ward, P. J., de Moel, H., and Aerts, J. C. J. H.: How are flood risk estimates affected by the choice of return-periods?, Nat. Hazards Earth Syst. Sci., 11, 3181-3195, doi:10.5194/nhess-113181-2011, 2011b.

Winsemius, H. C., Van Beek, L. P. H., Jongman, B., Ward, P. J., and Bouwman, A.: A framework for global river flood risk assessments, Hydrol. Earth Syst. Sci., 17, 1871-1892, doi:10.5194/hess-17-1871-2013, 2013.

World Bank: Climate Risks and Adaptation in Asian Coastal Megacities - a synthesis report, The World Bank, Washington, 120 pp., 2010.

World Bank: Rapid Assessment for Resilient Recovery and Reconstruction Planning, 2 The World Bank, Bangkok, 248 pp., 2012.

Zevenbergen, C., Gersonius, B., Puyan, N., and van Herk, S.: Economic feasibility study of flood proofing domestic dwellings, Chapter 13 in: Advances in Urban Flood Management, 299-318, 2007. 